\title{
Õpetaja professionalismi võimalikud tulevikustsenaariumid aastaks 2035
}

\author{
Krista Loogma ${ }^{a 1}$, Maria Erss $^{\mathrm{a}}$, Meril Ümarik ${ }^{\mathrm{a}}$ ja Maret Aasa ${ }^{\mathrm{a}}$ \\ a Tallinna Ülikooli haridusteaduste instituut
}

\begin{abstract}
Annotatsioon
Kiired üleilmsed muutused mõjutavad õpetajatööd ja -ametit. Artikli eesmärk on selgitada võtmetegurid, mis mõjutavad ootusi õpetaja professionaalsusele, ning konstrueerida tulevikustsenaariumid 2035. aastani, et tuua esile võimalikud alternatiivsed arengurajad ja neile suundumist mõjutavad võtmetegurid üldhariduse kontekstis. Stsenaariumide peamine funktsioon pole ennustamine, vaid pigem püüd tulevikku ennetada, ärgitades selle üle arutlema ning hariduspoliitika strateegilisel planeerimisel võimalike tulevikuteedega arvestama. Stsenaariumimeetod põhineb tuleviku võtmetegurite valikul, nende vastastikuse mõju analüüsil ja stsenaariumide lugude koostamisel. Stsenaariumide aluseks valitud õpetaja töökeskkonda oluliselt mõjutavad võtmetegurid on võimalikud muutused õpetajate ametisse sisenemisel ja alternatiivsed haridustehnoloogia arengutendentsid. Nende kahe dimensiooni alusel on visandatud neli võimalikku õpetaja professionalismi stsenaariumi: „digitark arengusuunaja“, „tehnoloogiakaubamaja instruktor“, „biheivioristlik tööampsutaja“ ja „arenguline paradoks“.
\end{abstract}

Võtmesõnad: professionalism, õpetajad, stsenaariumimeetod, tuleviku võtmetegurid

\section{Sissejuhatus}

Õpetajatöö ja -kutse on teinud viimastel kümnenditel läbi suuri muutusi ning tulevikus võib ette näha veelgi suuremaid ühiskondlikke, majanduslikke ja hariduse valdkonda puudutavaid murrangulisi muutusi seoses globaliseerumise ja määramatuse kasvuga laiemalt (OECD, 2018).

Eesti taasiseseisvuse ajal õpetajatööd kujundanud sotsiaalmajanduslikus ja kultuurilises keskkonna mitmekihilised muutused tulenesid ühelt poolt globaalse iseloomuga laiemate trendide, nn megatrendide mõjust. Teiselt poolt

Haridusteaduste instituut, Tallinna Ülikool, Narva mnt 25, 10120 Tallinn; loogma@tlu.ee. 
mängis rolli see, kuidas toimib rahvuslik hariduskeskkond nii nende trendide kui ka rahvusliku sotsiaalmajandusliku ja ajaloolis-kultuurilise keskkonna ning hariduspoliitika koosmõjul. Nii võivad samad megatrendid tuua haridusele ja õpetajate professionalismile riigiti kaasa erineva mõju (Seddon, 2013).

Olulisi väljakutseid esitavad meie rahvastiku olukord ja muutuvad peremudelid, tehnoloogia rakendamine kõikides eluvaldkondades (sh hariduses), sotsiaalne ebavõrdsus (sh regionaalne), määramatuse kasv seoses muutustega tööturul, ühiskonna keeleline ja kultuuriline mitmekesistumine ning kultuuriliselt diferentseerunud õpilaskond, aga ka ühiskonnas suurenev infomüra ja turvalisuse kahanemine. (Lauristin, Loogma, Vernik-Tuubel, Kutsar, Erss, Kallas, Sildnik, Käosaar, 2019; Arenguseire Keskus, 2018).

Õpetaja ametiga seonduvateks kõige kriitilisemateks tulevikuprobleemideks võib pidada õpetajaameti staatuse, autonoomia ja enesetõhususe küsimusi ning nendega seotud struktuurset õpetajate puudust, vähest järelkasvu ja noorte õpetajate läbipõlemist (Loogma, 2014; Mets \& Viia, 2018). Õpetajate järelkasv ei kata asendusvajadust, kuna õpetajakutse ei ole noorte seas populaarne (nt PISA uuringus (OECD, 2016b) vastas vaid 0,6\% eesti 15 -aastastest noortest, et soovib saada õpetajaks). Ligi pool õpetajakoolituse lõpetajatest ei asu õpetajana tööle (Valk, 2016). Alustavatest õpetajatest 30\% lahkub koolist pärast esimest tööaastat. Samuti on kasvanud keskealiste õpetajate (40-49) lahkumine koolist (EHIS).

Kuigi õpetajate palk on samm-sammult tõusnud ja ületab riigi keskmise palga taseme, on õpetaja heaolu pigem kahanenud ja õpetajad on kooli suhtes kriitilised (Lauristin et al., 2019). Kaasava hariduse rakendamisel ei ole olnud õpetaja võimestamine (tugispetsialide abi, koolitused jm) piisav (Kolnes \& Konstabel, 2018). Ülekoormust tekitavad bürokraatliku asjaajamise, juhtimise, kooli arendamisega seotud ülesanded, mida on tunnistanud $47 \%$ õpetajatest (Rumma, 2017). Lisaks kogevad õpetajad solvanguid ja isegi kiusamist (Kõiv, 2015, 131; OECD, 2019a). Eelnevaga seoses kannatab õpetamise kvaliteet ja õpetajate tajutud enesetõhusus. Positiivsena võib näha, et 2018. aasta TALISe andmetel on Eesti õpetajate enesetõhusus siiski pisut tõusnud (OECD, 2019). Need on kitsaskohad, millega peab Eesti hariduspoliitika kujundamisel arvestama.

Artiklis kajastatavas uuringus rakendatakse stsenaariumi meetodit (Ramirez \& Wilkinson, 2014). Eesmärk on kirjeldada õpetaja professionalismi tulevikku määravad võimalikud võtmetegurid ja koostada neli alternatiivset visiooni õpetaja professionalismi võimalikest arenguradadest, lähtudes praegusest olukorrast aastani 2035. 


\section{Õpetajate professionalism - kontseptuaalne raamistik ja hetkeseis}

Õpetajate ametirühmast rääkides kasutame õpetajate professionalismi kontseptsiooni kui sotsiaalselt konstrueeritud arusaama õpetaja ametist kui professioonist (Goodson, 2003).

Freidsoni (2001) nn traditsioonilise professionalismi määratluse kohaselt saab professiooniks nimetada ametirühma, mida iseloomustab: 1) ametirühma eneseregulatsioon, mis tähendab ametirühma kontrolli oma tööülesannete sisu, tööjaotuse, tingimuste ja tulemuste üle; 2) akadeemiline haridus ja teadusliku teadmiste baasi olemasolu; 3) kõrge staatus, mõjuvõim ja privileegid ühiskonnas; 4) kontroll ametirühma sisenemise tingimuste üle; 5) spetsiifiline ideoloogia ja professionaalne eetika. Tuleb võtta arvesse, et selle käsitluse puhul on tegemist ideaalmudeliga. Näiteks kui Freidson (2001) defineerib professionalismi ametirühma eneseregulatsiooni ehk võime kaudu oma tööd kontrollida, siis tegelikkuses pole tööd, mida ametirühm ise täielikult kontrolliks (Ruus, 2006). Professionalismi mõjutavad poliitika, ühiskondlikud jõud, tööturg (Noordegraaf, 2007). Ehkki Freidsoni esitatud ideaaltüüp pole reaalsuses saavutatav, on see sobiv lähtepunkt õpetaja ametiga seotud muutuste mõtestamiseks.

Hilisemad autorid on lisanud õpetaja professionalismi käsitlustesse uusi aspekte. Näiteks rõhutab Hargreaves (2006) oma kollegiaalse professionalismi idee kaudu õpetajatevahelise koostöö olulisust. See on muutnud arusaama õpetajate autonoomiast, mis individuaalse tegutsemise asemel tähistab nüüd pigem valikuvabadust ja võimet teha isiklikke otsuseid kollektiivsete piirangute ja võimaluste raames (Evetts, 2013). Autonoomia mõistmine kollektiivse tegutsemise vormina annab uue tähenduse professionaalsele koostööle, mis TALIS 2013 andmetel on Eestis paraku suhteliselt vähene (Übius et al., 2014).

Evetts (2013) eristab organisatsioonilist ja ametrühmast lähtuvat professionalismi. Kui professionalismi varasemad käsitlused hõlmasid eelkõige professionaalide individuaalset ametialast tegevust, siis organisatsiooniline professionalism vaatleb nende tööd piirangute ja ootuste vaatenurgast, mida esitavad töötajatele üha arvukama töötajaskonnaga suured organisatsioonid (Evetts, 2014). Noordegraafi (2007) väljapakutud hübriidprofessionalismi kontseptsioon tähistab professionaalse ja organisatsioonilise tegevuse sulandunud rakendamist, misjuures organisatsioonide nõudmisi ja professionaalide huvisid ei pea tingimata käsitlema konfliktsetena, nagu sotsioloogilistes uurimustes on üldiselt arvatud, vaid need on tihti ajalooliselt kujunenud sümbioosis (Kirkpatrick \& Noordegraaf, 2015).

Hoyle (1975) on eristanud õpetajate professionalismi professionaalsusest, kuigi need on omavahel seotud. Kui professionalism viitab ametirühmale, 
siis professionaalsuse all mõistab Hoyle õpetajatöö individuaalseid elemente: teadmisi, oskusi, väärtusi. Seejuures võib professionaalsus olla nii piiratud (restricted) kui ka avaravaateline (extended). Piiratud professionaalsus tähistab eelkõige õppimist oma kogemusest ja intuitiivset tegutsemist klassiruumis ning avaravaateline professionaalsus iseloomustab õpetajat, kes arendab ennast, väärtustab teoreetilist teadmist, koostööd kolleegidega ning võtab vastutuse haridusprotsesside suunamise eest laiemalt koolis ja ühiskonnas. Nähes õpetaja laiemat sotsiaalset rolli (Hoyle, 1975), pühendub ta kasvatustööle ja sotsiaalsetes võrgustikes osalemisele.

Analüüsides õpetajaameti hetkeseisu lähtuvalt professionalismi võtmetunnustest - autonoomiast, staatusest ning jagatud ideoloogiast (Freidson, 2001; Loogma, 2014), - võib näha, et ametirühma on mõjutanud kompleks tegureid, sealhulgas standardiseerimine, uusliberalistlikud väärtused, muutused rahvastikus ja õpilaskonna mitmekesistumine, tehnoloogia areng.

Kui ühelt poolt võimaldab õpetajatöö standardimine õppe kvaliteeti ja professionaalsust toetada (Pedaste, Leijen, Poom-Valickis \& Eisenschmidt, 2019), siis teiselt poolt piiravad riiklikud standardid, sealhulgas õpetaja kutsestandard ja riiklik õppekava, õpetajaskonna autonoomiat ja võimalusi hoida oma tööd kontrolli all. Autonoomiat hakkas märkimisväärselt piirama 1997. aastal sisse viidud riigieksamite süsteem. Riiklik õppekava peegeldab autonoomia diskursuse muutust. Kui 1996. aasta õppekavas oli rõhk õpetaja individuaalsel ja kooli autonoomial, siis 2002. ja 2011. aasta õppekavas on rõhk nihkunud õpetajate kollektiivsele autonoomiale ja vastutusele (Erss, 2015). Reguleerimise tulemusel on Eesti õpetaja autonoomia ja iseseisev otsustamise õigus taandunud põhiliselt klassiruumi tegevustele ning on suurem neis ainetes, kus pole riigieksameid (Erss, Kalmus \& Autio, 2016, 15).

Õpetajaameti staatust peegeldavad palk, ametirühma järelkasv ning ka õpetajate endi subjektiivne hinnang oma tööle ja ametile. Kui valdav osa õpetajatest (90\%) oli konkreetses koolis oma töö ja töötulemustega üldiselt rahul (89\%), siis palju negatiivsemad olid hinnangud õpetajaameti ühiskondlikule staatusele (Übius, Kall, Loogma, Ümarik, 2014). Siiski näitavad TALIS 2018 uuringu tulemused, et võrreldes viie aasta taguse küsitlusega kogevad õpetajad ópetajaameti staatust tunduvalt positiivsemana (OECD, 2019a).

Spetsiifiline professionaalne ideoloogia ja kutse-eetika on samuti üks ametirühma iseloomustavaid tunnusjooni. Eesti õpetajaskonna väärtuspõhised kokkulepped ja tegutsemise printsiibid on esitatud 2005. aastal vastu võetud Eesti õpetajaeetika koodeksis (Eesti Õpetajate Liit, 2005). Kesksete väärtustena nimetatakse väärikust, ausust, õiglust ja iseseisvust. Iseseisvus rõhutab õpetaja agentsust, sealjuures õigust järgida otsustamisel isiklikke veendumusi ja väärtushinnanguid. Eesti õpetajaeetika koodeks rõhutab laiemat pilti õpetaja 
rollist. Õpetajas nähakse elukestvat õppijat, kes ei piirdu aine õpetamisega, vaid kujundab õppija väärtushinnanguid, koolikultuuri ja haridusmaastikku ning panustab koostöös kolleegidega ühiskondlikesse protsessidesse. Seega haakub Eesti õpetajaeetika koodeksis toodud õpetaja käsitus Hoyle'i laiendatud professionaalsuse kontseptsiooniga (Hoyle, 1975, 2001). Viimasega haakub ka Eesti haridusvisioon aastaks 2035 („Tark ja tegus Eesti 2035“, 2019), mis näeb ette keskse haridusmuutusena individualiseeritud õpiteede ja õmblusteta õpikeskkonna kujunemise. Kontseptsioon arvestab õppija erinevaid huve, vajadusi, suutlikkust ning hõlmab ja ühendab õppimise eri keskkondades (kool, töö, virtuaalsed keskkonnad jm), mis eeldab õpetaja rolli muutust. Õpetajast peaks saama arengu toetaja, kes aitab eri kontekstides õpitut mõtestada.

\section{Stsenaariumi meetod}

Tulevikustsenaariumid on tuleviku ennetamise ja tuleviku sotsiaalse konstrueerimise vahend (Fuller \& Loogma, 2009). Tulevikustsenaariumid võivad sõltuda suurest hulgast võimalikest teguritest, millest osa on analüüsitava nähtuse suhtes pigem välistegurid, st nende mõju on möödapääsmatu, kuid nendega peab arvestama (näiteks tehnoloogia, rahvastikuprotsessid), osa aga sisetegurid, mis sisaldavad (haridus)poliitilisi valikuid (Schwartz, 1991). Välised tegurid on laiaulatuslikud ja läbivad kõiki valdkondi, mõjutades õpetaja professionalismi pigem väliskeskkonna muutumise kaudu. Sisemised tegurid on otseselt õpetajaametiga seotud ning sõltuvad enam hariduspoliitilistest otsustest.

Tuleviku arengu analüüsimisel tuleb komplekssuse vähendamiseks valida võimalike hulgast välja võtmetegurid ehk tulevikuarengut suunavad mõjujõud (driving forces), mis saavad tulevikustsenaariumide konstrueerimise eeldusteks. Võtmeteguritega ei saa põhimõtteliselt hõlmata kõiki potentsiaalselt võimalikke arenguteid, kuid valitud võtmetegurid peavad olema tuleviku (siin õpetaja professionalismi) seisukohalt olulised ning samas ka kõrge määramatuse astmega (Schwartz, 1997).

Stsenaariumid esindavad tulevikuolukordi ja nendeni jõudmise tingimusi lugude kaudu, mis lähtuvad olemasolevast olukorrast, toetuvad võtmeteguritega määratud eelduste võrgustikule ja püüavad arvestada, kuidas olulisemad, ja samas suure määramatusega võtmetegurid võiksid mõjutada mingi nähtuse või süsteemi võimalikke tuleviku arenguteid (Spaniol \& Rowland, 2018, 9; Ramirez \& Wilkinson, 2014). Stsenaariumid pole tõendatud lõplikud seisukohad tuleviku kohta, vaid on vahendiks orienteerumaks tulevikku kujundavates võtmetegurites ning pigem alguspunktid dialoogiks. (OECD, 
2001). Kuna stsenaariumid hõlmavad vaid piiratud tegurite kombinatsioone lõpmatute tulevikuvõimaluste seas, ei saa nad kunagi puhtakujuliselt realiseeruda (Ramirez \& Wilkinson, 2014).

Stsenaariumide konstrueerimine selles artiklis toetub nn stsenaariumide koostamise intuitiivsele loogikale, kasutades 2 × 2 stsenaariumide koostamise meetodit (Ramirez \& Wilkinson, 2014; Spaniol \& Rowland, 2018). Seda meetodit on enim kasutatud eelkõige selguse ja läbipaistvuse tõttu (samas). Stsenaariumide ajahorisont on 2035. aasta, mis kattub uue haridusstrateegilise planeerimise perioodiga Eestis (HTM, 2019).

Stsenaariumide koostamine koosneb järgmistest sammudest. Esiteks, olemasoleva olukorra analüüs ja kirjeldamine, toetudes eelnevate uuringute andmetele ja tulemustele (vt sissejuhatust ja eelmist peatükki). Teiseks, õpetaja professionalismi olukorda mõjutavate tegurite analüüs. Kolmandaks, võtmeteguritest ehk suunavatest mõjujõududest (driving forces) valitakse kaks olulisimat: üks välis- ja üks siseteguritest. Nende valikul arvestatakse järgmisi tingimusi: kaks valitut on teineteisest sõltumatud, kuid samas suurima määramatuse astmega, esindades tegureid, mis kujundavad võimalikke õpetaja professionalismi arengu keskkondi. Nii ajendavad nende alusel koostatud narratiivid mõtlema tulevikule ja võimalike probleemide ennetamisele. (Ramirez \& Wilkinson, 2014) Neljandaks, kahele valitud võtmetegurile omistatakse võimalikud tulevikuväärtused ehk võimalikud suundumused, mis on hüpoteetilised ega saa haarata kõiki tulevikuvõimalusi. Võtmetegurite ja nendele antud tulevikuväärtuste alusel koostatakse maatriks, mis kujutab stsenaariumide raamistikku. (Schwartz, 1991; Ramirez \& Wilkinson, 2014; Spaniol \& Rowland, 2018, 4) Valitud eeldustel (võtmeteguritel) põhinev raamistik struktureerib võimalikke tuleviku keskkondi, milles õpetaja professionalismi arengustsenaariumid konstrueeritakse. Stsenaariumid esitatakse lugudena, mis peavad olema võimalikud ja sisemiselt koherentsed (Spaniol \& Rowland, 2018, 11).

\section{Õpetaja professionalismi tulevikku mõjutavad tegurid}

Selles peatükis avame kõigepealt olulisemaid õpetaja professionalismi kujundavaid väliskeskkonna tegureid, milleks on ideoloogia, rahvastikuprotsessid, õpikeskondade muutus ja haridustehnoloogia areng. Nendest valisime üheks võtmeteguriks haridustehnoloogia arengu kui kõige globaalsema ulatusega teguri. Sisetegurite hulka kuuluvad need, mis on otseselt õpetaja professionalismiga seotud ning riiklikest poliitikatest suuresti mõjutatavad, nagu õpetajate töötasu, õpetajatele esitatavad formaalsed nõuded, õpetajaametisse sisenemine (vt eelmist peatükki ja alapeatükki „Sisenemistee õpetajakutsesse kui 
sisekeskkonna tegur"). Neist valisime teiseks võtmeteguriks õpetajaametisse sisenemisteed seetõttu, et need on seotud õpetajaameti juurprobleemidega Eestis ja maailmas: ópetajate professionaalse ettevalmistuse ja arengu, staatuse ning struktuurse puudusega (OECD, 2005; Valk, 2016; Lauristin et al., 2019)

Seejärel analüüsime nende kahe valitud võtmeteguri võimalikke suundumusi tulevikus. Haridustehnoloogia puhul on kaheks võimalikuks suundumuseks tulevikus ühelt poolt instrumentaalne ja teiselt poolt arenguline suundumus. Õpetajaametisse sisenemisteede puhul on arvestatud järgmiste võimalike suundumustega: pigem avatud ning pigem suletud sisenemisteed.

\section{Välistegurid}

\section{Ideoloogia}

Kuigi Eesti hariduspoliitika on saanud mõjutusi eri väliseeskujudest ja ideoloogiatest, on alates 1990ndate lõpust praeguseni haridusväärtusi Eestis kujundanud peamiselt uusliberalistlik ideoloogia. See on muutnud võimusuhteid ja suurendanud õppijate ja lapsevanemate mõjuvõimu. Uusliberalistlik ideoloogia, mille järgi turu „nähtamatu käsi“ reguleerib kõike (Olssen, Codd, \& O'Neill, 2004), on alates 1980. aastatest muutnud õpetajaametit ja -tööd kogu maailmas. Seda on kirjeldatud pigem deprofessionaliseerimise diskursuses, rõhutades turuprintsiipide rakendamist avaliku sektori hariduses, standardite ulatuslikku rakendamist ja aruandekohustuse suurenemist, mis on viinud õpetaja heaolu alanemiseni, õpetajate puuduse ja järelkasvu probleemideni mitmes Euroopa riigis (Ball, 1994; Raidt, 2009).

Uusliberalismi paradoks on see, et mida rohkem autonoomiat antakse koolidele ja õpetajatele õppeprotsessi üle, seda suuremaks paisub turu surve ja aruandlus õpitulemuste üle (Ball, 1994, 66). Nii näiteks viidi koos koolide autonoomia ja kooliõppekava seadustamisega Eestis 1996.-1997. aastal paralleelselt sisse riigieksamite süsteem (Erss, 2015, 66). Siiski pole praegu Eestis valitsev haridusideoloogia puhtakujuline uusliberalism, vaid ka segu konservatiivsest ja sotsiaaldemokraatlikust ideoloogiast.

\section{Rahvastikuprotsessid}

Kooli ja õpetaja tööd mõjutavad rahvastiku vananemine, hargmaisus ja sisseränne. Rahvastiku vähenemine suurendab ootusi haridusele, et toetada iga inimese arengut kogu elukaare jooksul. Perekonna struktuuri muutused ja hargmaine elustiil toovad kaasa perekonna vastutuse teisenemise laste ja noorukite hariduse eest ja mõjutavad laste hariduses osalemist (OECD, 2016a; Mets \& Viia, 2018), ootusi üha paindlikumate haridusvõimaluste järele ja 
õpetaja rollide laienemist, sealhulgas õpetaja kasvatusrolli suurenemist (Sirk et al., 2017).

Laieneva rände ja hargmaisuse mõjul muutub Eesti elanikkond kultuuriliselt ja keeleliselt mitmekesisemaks, mille toimel peavad süvenema nii keele- kui ka kultuuripädevused ning samal ajal peab haridus toimima ka ühiskonna kultuurilise sidususe kujundajana (Lauristin et al., 2019). Üha enam diferentseeruv õpilaskond nõuab mahajääjate ja andekate õppijate, aga ka erivajadustega õppijate lahknevatele vajadustele vastamist (samas). See soosib individuaalsete õpiteede kujunemist, kuid esitab väljakutseid koolidele ja õpetajatele.

\section{Õppimise keskkonnad}

Postmodernistliku mõtte ajastul on muutunud küsitavaks modernistlik praktika, mille järgi kõik õppijad peavad läbima sama õppesisu samas rütmis (Doll, 1993). Üha diferentseeruv õpilaskond on erinevate vajadustega. Niisiis on vältimatu, et õpirajad individualiseeruvad (Räis \& Sõmer, 2016) ning hariduse pakkumine muutub paindlikumaks.

Enesestmõistetavaks on muutunud, et õppimine toimub väga erinevates keskkondades, mis on sümbioos informaalsest, formaal- ja mitteformaalharidusest. Eelkõige pälvib viimasel ajal rohkem tähelepanu õppimine väljaspool formaalset õpikeskkonda, näiteks huviharidus ning osalemine autentsetes sotsiaalsetes keskkondades (Selliov, 2017, 5), mis võimaldavad õppida päriselu probleemide kohta „praktika kogukondades“ ning omandada sellega kogukonna liikme identiteedi (Lave \& Wenger, 1991, 65). Kõige enam uuritud autentseteks õpikeskkondadeks võib pidada töökohal õppimist (Tynjälä, 2008).

\section{Haridustehnoloogia areng}

Õpetajakutset mõjutavates teguritest võib pidada üheks kesksemaks tehnoloogiat ja selle võimalikke arengusuundi hariduse kontekstis ${ }^{2}$. Haridustehnoloogia võib juba lähiaastatel tuua kaasa suuri muutusi õpetajaametis (Arenguseire Keskus, 2018), mõjutades seda nii tulevikumaailmas eluks ja tööks vajalike pädevuste nõudmise kaudu kui ka haridustehnoloogia, sealhulgas õpetamisel ja õppimisel tehisintellekti rakendamise kaudu (Tuomi, 2018, 2013). Haridustehnoloogia muudab õpetajate ja õpilaste suhteid ning sunnib ulatuslikult ja kompleksselt kohandama õppekavasid (Scrimshaw, 2003). See võimaldab luua tulevikus paindlikuma, personaalsema ja mitmekesisema

„Haridustehnoloogia alla kuuluvad kõik tehnoloogiad, mis aitavad õppida ja õpetada“ (Luik, 2013, 106). 
õpikeskkonna õpivõrgustike ja -kogukondadena ning toetada erivajadustega õppijaid.

Hoolimata mitmekülgsusest peetakse tehnoloogilisi võimalusi hariduses seni pigem alakasutatuks (Fullan, 2013). Samas nähakse, et tehnoloogia arengu, õppimise ja õpetamise efektiivistamise ja tehnoloogiatööstuse huvi tõttu kasvab surve tehnoloogiate rakendamiseks haridusinstitutsioonides ja praktikas kiiresti ja jõuliselt (Regan \& Khwaja, 2019). Seega on tehnoloogial potentsiaal käivitada murrangulisi muutusi hariduses.

Tehnoloogia üldiselt muudab pidevalt keskkonda, milles koolid ja õppijad tegutsevad. Näiteks muutuvad töös nõutavad pädevused tööde ja avalike teenuste automatiseerimise, töötamise viiside muutumise ja üleüldise töö ebastabiilsuse kasvu jm asjaolude tõttu (Mets \& Viia, 2018; Arenguseire Keskus, 2018). Tehnoloogia võib praeguste, endistelt industriaalühiskonna vajadustele kohanenud haridussüsteemide funktsioone oluliselt muuta, võimaldades uusi õppimise ja õpetamise viise, õpikeskkondi ning mõjutades seeläbi õpetaja tööd tulevikus. Tehnoloogia võib olla nii õpetaja abimees üksikute õpetamistegevuste puhul, täiendades olemasolevaid praktikaid, asendades ja tõhustades üksikuid tegevusi, kui ka viia kvalitatiivsete muutusteni (OECD, 2016a, Tuomi, 2018). Näiteks võib tehnoloogia viia automatiseeritud kooli kujunemiseni, kus ópetaja loob ja kontrollib õppesisu ja -keskkonda (samas), kuid hindamine, tagasiside ja juhendamine jäävad virtuaalsete tuutorite ja robotite ülesandeks (Edwards \& Cheok, 2018).

Praegu on haridustehnoloogiat rakendatud peamiselt õppimise hindamisel, õpianalüütikas, haridusandmete kaevel, masinõppes keeleõppimisel ja tõlkimisel (Tuomi, 2018, 32), ning õppimisviiside puhul, kus on vajalik individualiseeritud lähenemine, nagu distantsõppel (Mac Iver \& Mac Iver, 2015) ja erivajadusega õppijate toetamisel (Bjekic, Obradovic, Vučetic, \& Bojovic 2014), mis pole saavutatav traditsioonilises õpikeskkonnas (Kalyuga \& Liu, 2015). Oma olemuselt on need lahendused seotud aga peamiselt üksikute õpetaja töölõikude või tegevuste automatiseerimisega, toetudes pigem lihtsustatud ja biheivioristlikele õppimise käsitustele (Tuomi, 2018, 32).

Ometi nähakse tehnoloogia, eriti haridustehnoloogia potentsiaali teadmiste uutmoodi loomisel, esitamisel, jagamisel ja loomingulistes väljendusvõimalustes (Henriksen, Mishra, \& Fisser, 2016). Õpetaja peab oskama hinnata haridustehnoloogiate potentsiaali ja piiranguid, eri keskkondade sobivust, osalema võrgustike arendusprotsessis, arendama õppijate õppimisoskusi paindlikus ja avatud õpikeskkonnas (Tuomi, 2018). Ópetajaamet ei kao, kuid eeldatavasti muutub tema roll (Mets \& Viia, 2018) ning tõenäoliselt muudab haridustehnoloogia rakendamine õppetöös õpetaja töö veelgi mitmetahulisemaks ning ettevalmistuse komplitseeritumaks. 
Oluline on õpetajate professionaalne ettevalmistus ja areng, mis võimaldaks õpetajatel tehnoloogiast kasu saada, nõustada ja toetada õppijate arengut, sealhulgas tegutseda käsikäes virtuaalsete juhendajatega (OECD, 2016a). Tuomi (2018) eeldab haridustehnoloogia arengus erinevaid võimalikke suundumusi ning on selgitanud, et tehnoloogia potentsiaalne mõju õpetamisel hakkab tulevikus sõltuma nõudlusest ja sellest, millised õppimise mudelid võetakse hariduses tehnoloogiate disainimisel aluseks. Nii võib haridustehnoloogia areng tulevikus põhineda a) instrumentaalsusel või b) arengu toetamisel. (OECD, 2016a). Haridustehnoloogia on valitud stsenaariumide üheks võtmeteguriks (välisteguriks) eelkõige selle kiire arengu, võrgustike kaudu toimuva kiire globaalse leviku ja kõiki eluvaldkondi läbiva mõju tõttu (nt OECD, 2018; OECD, 2019b).

\section{Haridustehnoloogia: instrumentaalne suundumus}

Instrumentaalse suundumuse puhul õpetatakse tehnoloogia abil peamiselt aine- või erialaspetsiifilisi teadmisi ja oskusi. Õpetajatöös automatiseeritakse üksikuid toiminguid (nt hindamisega seotud testid), toetudes suurandmetele ning pigem biheivioristlikele õppimise käsitlustele, arvestamata tuleviku õppimise ja töötamise võimalikku konteksti. (Tuomi, 2018). Tehnoloogia toel toimivat õpikeskkonda nähakse eelkõige õpetaja käepikendusena, õppimist ja õpetamist toetava ja rikastavana, individuaalselt kohandatava ja paindlikuna.

Nõudlus instrumentaalsete lahenduste järele tuleneb majanduslikest kaalutlustest ja õpetajate puudusest, mistõttu võidakse eelistada õpetajana mitteinimesi (Edwards \& Cheok, 2018). Instrumentaalset lähenemist toetab ka vajadus kohanduda pideva tööprotsesside automatiseerimisega ning sellest tuleneva muutuva pädevuste nõudmisega tööturul. Eesti kontekstis ei saa alahinnata ka e-riigi kuvandist tulenevat survet. See suundumus võib viia tehnoloogilise optimismi ja tehnoloogia ebakriitilise rakendamiseni. Tehnoloogias nähakse lahendust olemasolevatele probleemidele (nt õpetajate aja kokkuhoid) (Tuomi, 2018).

\section{Haridustehnoloogia: arenguline suundumus}

Haridustehnoloogia arenguline suundumus eeldab, et formaalharidus on suunatud pigem inimpotentsiaali üldisele arengule kui konkreetseks tööks või tegevusteks ettevalmistamisele. Tehnoloogia arendamise funktsiooniks kujuneb üldiste pädevuste (ülekantavad pädevused, 21. sajandi pädevused) arendamise toetamine. Tehnoloogilised lahendused toetuvad siinjuures peamiselt sotsiaalkonstruktivistlikele ja sotsiaalkultuurilistele lähenemistele õppimisel (Tuomi, 2018), et toetada tähendusloomet. Selliste lahenduste loomine eeldab aga 
tuleviku õppimiskeskkondade visioneerimist, sealhulgas üha mitmekesisemate ja enam avatud õppimise keskkondadega arvestamist (Lauristin et al., 2019). Teadvustatakse haridustehnoloogia kasutamise negatiivseid kõrvalmõjusid.

Haridustehnoloogia võimaluste kõrval hinnatakse kriitiliselt ka negatiivseid kõrvalmõjusid. Näiteks rohkete hüperlinkidega õpikeskkondade mõju, mis tasakaalustamata rakendamisel võib tekitada õppimisvõimet pärssivat kognitiivset ülekoormust (Kalyuga \& Liu, 2015), süvenemisraskusi (O’Donnell, 2015), vähendada kriitilist mõtlemist, kujutlus- ja refleksioonivõimet (Greenfield, 2009). Väljakutseks võib kujuneda õpilaste andmete kaitse ja privaatsuse tagamine (Serholt et al., 2017). Lahenduseks on tehnoloogia üldisest arengust muutunud sotsiaalse keskkonna tunnustamine, muutunud õppimise ja õppija identiteedi toetamine ning haridustehnoloogia mõtestatud ja kriitiline integreerimine (nt Rosenfeld, 2015). Digitaalne kirjaoskus tähendab ühtaegu ka arusaamist, et haridustehnoloogiline surve on seotud poliitiliste (nt Selwyn, 2013) ja tehnoloogia arendajate majanduslike huvidega (Hrastinski et al., 2019), mistõttu on haridustehnoloogia pideva uuendamise asemel mõttekam kasutada otstarbekamalt olemasolevaid lahendusi (Pötzsch, 2019).

\section{Sisenemistee õpetajakutsesse kui sisekeskkonna tegur}

Teiseks võtmeteguriks (siseteguriks) valisime õpetajaametisse sisenemise teed. Eri riikides on kasutusel erinevad õpetajakutsesse sisenemisteed ja karjäärimudelid. Mitmes Euroopa riigis (nt Saksamaa, Prantsusmaa ja Hispaania) on kasutusel nn avaliku teenistuse eluaegne karjäärimudel, kus sisenemine õpetajakutsesse on piiratud ja kandidaatidele esitatavad nõuded on kõrged (ülikooliõpingud ja riiklike kutseeksamite läbimine), kuid tagatud on selge astmeline karjäär ja võrdlemisi helded pensionitingimused, mis annavad õpetajale kui avaliku sektori teenistujale eelise erasektori ees. Selles süsteemis tavaliselt õpetajate puudust ei esine, aga süsteemi puuduseks peetakse seda, et õpetajatel ei ole tähtajatu töölepingu saavutamise järel tihti motivatsiooni panustada professionaalsesse arengusse. Muu hulgas võib see mudel peletada eemale head kandidaadid, kes ei taha õpetamisega tervet elu siduda. Nende probleemide kõrvaldamiseks soovitatakse paindlikumaid sisenemisteid õpetajakutsesse, lubades teiste erialade inimestel kandideerida õpetajaks ning võimaldades paindlikku liikumist eri karjääriradade vahel (OECD, 2005).

Riikides, kus soositakse ealiselt ja haridusliku tausta poolest paindlikke sisenemisteid õpetajakutsesse, nagu Ühendkuningriik, Kanada, Rootsi ja Šveits, antakse kohalikule koolile ja kogukonnale suuremad volitused personaliotsuste tegemisel. Kuigi palk ametisse sisenemisel on nendes riikides küllaltki atraktiivne, saavutab see kiiresti oma lae, sest kõrgema positsiooniga kohtade arv 
on piiratud. Sellise süsteemi puhul tekib kiiresti õpetajate puudus aladel, mis pakuvad erasektoris märksa kõrgemaid palku ja paindlikumaid tingimusi, nagu IKT, matemaatika ja loodusained. Süsteem ei soodusta õpetajate kutsekindlust ja kogenud õpetajaid on raske koolis hoida. Eriti torkab ópetajate voolavus silma sotsiaalselt mahajäänud piirkondades ning tulemuseks on koolide suur erinevus õpetajate kogemuses ja kvaliteedis (OECD, 2005, 8-9). Et õpetajate ebaühtlasest tasemest tulenevaid erinevusi tasandada, on näiteks Ühendkuningriigis üritatud kontrollida õpiväljundeid nn õpetajakindla õppekava ja standardtestidega, mis on kahandanud õpetajate autonoomiat (Ball, 2006) ning süvendanud avalikkuse usaldamatust õpetajate vastu (Pinar, 2004). Suurenenud kontrolliga kaasnevad õpetajate negatiivsed reaktsioonid on viinud õpetajate kutsekindluse kriisini (Hargreaves \& Shirley, 2009, 11). Avatud sisenemise poliitika seostub uusliberaalse ideoloogiaga, mille järgi avatud turg ja konkurents parandab kvaliteeti ning suurendab valikuvabadust.

Artiklis käsitleme ametirühma sisenemist kui õpetajate professionalismi stsenaariumide koostamise aluseks olevat sisetegurit. Nimetatud sisetegur on kõrge määramatuse tasemega. Näeme, et ühelt poolt on Eesti õpetajate kvalifikatsioonitingimused muutunud aasta-aastalt rangemaks - kehtivate nõuete (RT I, 2013, 5) järgi on põhikooli- ja gümnaasiumiõpetaja kvalifikatsiooninõudeks magistrikraad. Õpetajakutse saadakse ülikoolis pärast õpetajakoolituse õppekava läbimist või kutset andva organi juures õpetajaametiks vajaliku pedagoogilise kompetentsi tõendamisel. Eesti õpetajate akadeemiline haridustase on üle OECD riikide keskmise (OECD, 2019a).

Teiselt poolt on koolijuhtidel õigus rakendada lühiajaliste lepingutega ka kvalifikatsiooninõuetele mittevastavaid õpetajaid ning tegelikkuses alustab üha enam õpetajaid (ligi pool) ametis vajaliku kvalifikatsioonita (Selliov \& Vaher, 2018). Paralleelselt üha rangemaks muutuvate kvalifikatsiooninõuetega, s.o suletud sisenemisteega on esile kerkimas alternatiivseid avatud sisenemisteid (nt programm „Noored kooli“), tööampse on võimalik teha praktikutel, osaledes nn asendusõpetaja programmis. Populaarseks õpetajaametisse sisenemise teeks on programm „Noored kooli“, mis kestab kaks aastat, mille vältel töötab osaleja koolis õpetajana ja läbib 60 ainepunkti mahus Tallinna Ülikooli õpetaja kõrvaleriala õpinguid. Programmis osalejat nähakse kui hariduse valdkonna eestvedajat ja juhti (programmi „Noored kooli“ koduleht).

Praegu võib näha paralleelseid tendentse nii avatud kui ka suletud ametirühma sisenemise suunas. Areng ühes või teises suunas sõltub hariduspoliitilistest valikutest ning sellel on selge mõju õpetajate professionalismi keskmes olevatele teistele teguritele: ópetajate pädevusbaasile ja autonoomiale, staatusele ning ameti eetikale. 


\section{Ametirühma sisenemistee: suurem suletus}

Professiooni iseloomustab klassikalise professionalismi käsitluse (Freidson, 2001) järgi range kontroll ametirühma sisenemise üle. Suletud sisenemistee tähendab akadeemilise hariduse ja teoreetilise teadmistebaasi olemasolu. Pikaajalised akadeemilised õpingud arendavad õpetajate ainealaste teadmiste kõrval samuti pedagoogilisi oskusi ning valmisolekut võtta laiemat rolli õppija väärtushinnangute, koolikultuuri ja haridusmaastiku kujundajana, panustada ühiskondlikesse protsessidesse. Selline käsitlus õpetajast haakub Hoyle’i laiendatud professionaalsuse kontseptsiooniga (Hoyle, 1975, 2001).

Võimalik tulevikutrend õpetajate ametirühma suletud sisenemistee poole (rangemad regulatsioonid koolidele õpetajate töölevõtmisel) tähendab, et akadeemiline ettevalmistus saab ainuvõimalikuks õpetajaametisse sisenemise teeks, laieneb õpetajate teadmiste baas ning valmisolek võtta kasvataja rolli. Õpetajate laienenud pädevustega kaasneb autonoomia kasv klassiruumis ja enesetõhusus oma töös. Kuna õpetajaks saamine ei ole igaühele jõukohane ning nõuab pikaajalise tasemeõppe läbimist, võib eeldada ka seda, et õpetaja staatus ühiskonnas kasvab.

\section{Ametirühma sisenemistee: suurem avatus}

Alternatiivse arenguteena võib avatus õpetajaametisse sisenemisel kasvada. Programmi „Noored kooli“ kõrval tekib teisi programme ja lühiajalisi koolituskursusi, mis annavad õpetajatööks baasettevalmistuse. Lühiajalised koolitusedkursused ei ole piisav keskkond, et kujuneks välja õpetaja professionaalne identiteet ja jagatud väärtused. Õpetajaameti maine pigem ei kasva, samas võib olla ajutiseks väljakutseks paljudele tööampsutajatele, kompenseerides seeläbi õpetajate põuda. Õpetajate hulgast võib leida paljude elualade esindajaid, kes rikastavad koolikeskkonda, kuid ei ole valmis võtma vastutust noorte arengu ja kasvatuse eest. Õpetajate ametirühm diferentseerub, haarates paljude erinevate vaadete, väärtuste ja pädevustega spetsialiste. Kindlustamaks pakutava hariduse kvaliteeti, kasvab kontroll õpetajatöö üle, õpetaja kui ametirühma autonoomia kahaneb.

\section{Stsenaariumid}

Esitame neli õpetaja professionalismi stsenaariumi, mis võivad realiseeruda kahe eespool kirjeldatud õpetajaametit mõjutava võtmeteguri tulevikusuundumuste koosmõjus. Stsenaariumid on esitatud kvadraatidena koordinaatteljestikus, kus horisontaaltelg kujutab kontiinumi avatuse ja suletuse vahel 
õpetajakutsesse sisenemisel ning vertikaaltelg instrumentaalse ja arengulise suundumuse vahel tehnoloogia rakendamisel. Stsenaariumide lood on koostanud autorid, võttes arvesse võtmetegurite eri suundumuste koosmõjusid.

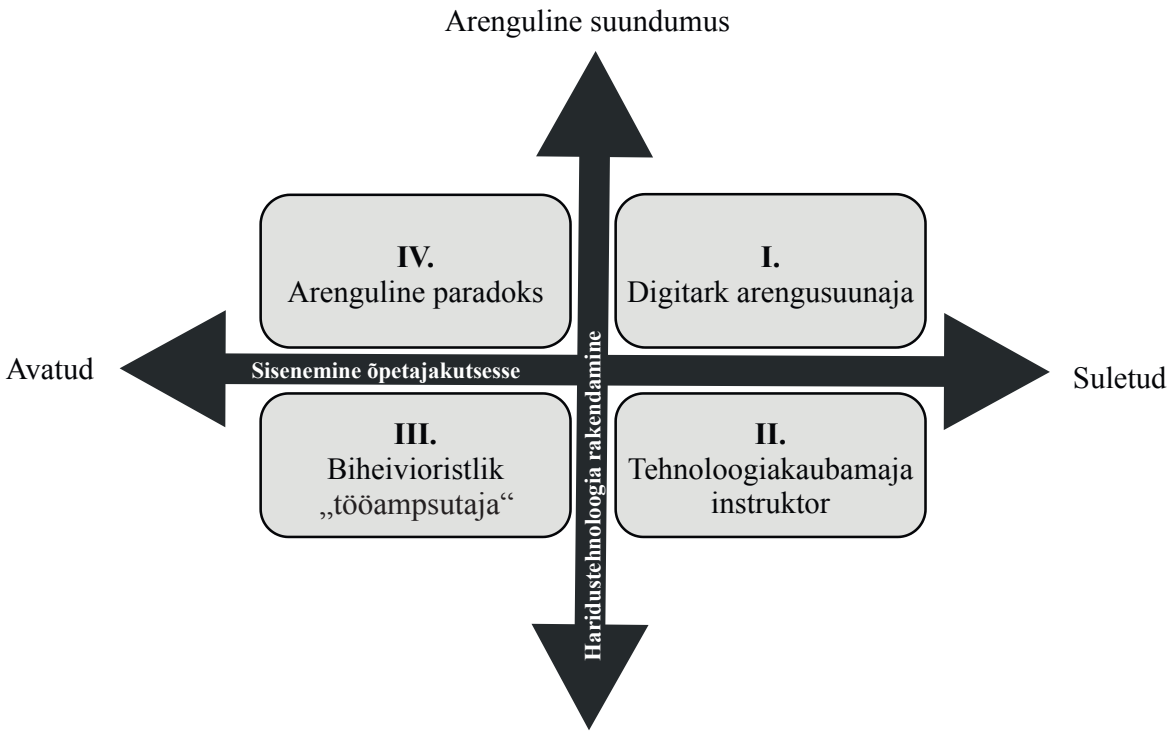

Instrumentaalne suundumus

Joonis 1. Õpetaja professionalismi võimalikud arengustsenaariumid.

\section{I „Digitark arengusuunaja“}

Kuigi praegu kuulub Eestis ametiühingusse ja aineühendustesse kokku ainult ligi pool õpetajatest ${ }^{3}$, on võimalik, et tulevikus võetakse eeskuju Soome õpetajate ametiühingust, millesse kuulub valdav enamik Soome haridustöötajaid: üheksa kümnest töötajast (OAJ koduleht). Haridustöötajate senisest suurem koondumine professionaalsetesse organisatsioonidesse ning õpetajate kasvav usaldus akadeemilise hariduse suhtes tugevdavad Soome eeskujul õpetajate professionaalset enesemääramisõigust, kindlustades kontrolli ametisse sisenemise tingimuste üle. Tehnoloogia senist rakendamist hakatakse üha kriitilisemalt hindama ning koos võimaliku tehisintellekti arenguga toob see potensiaalselt kaasa arengulise suundumuse haridustehnoloogias (Tuomi, 2018).

Intensiivistub ja laieneb tehnoloogiliste võimaluste roll ja kasutamine õppimisel ja õpetamisel. Kasutusele võetakse keerukaid ülesandeid teostav tehisintellekt, mis võimaldab õpetajal anda tehnoloogia kanda rutiinsed ülesanded,

3 Eesti Haridustöötajate Liitu kuulus 2017. aastal ligi 6000 liiget (Voltri, 2017, 10. nov) ning üle 30 aineliidul on liikmeid veel ligi paar tuhat. Võrdluseks: 2018/2019. aastal töötas üldhariduskoolides 15465 õpetajat (HTM, 2019). 
toetades õpetajat ühtlasi õppija nõustamisel, sotsiaalsete oskuste ja loovuse arendamisel. Kuna koolidele suunatud tehnoloogia kujuneb tehnoloogiaettevõtete kasumiallikaks, suureneb nende surve haridusasutustele (Hrastinski et al., 2019), mille tasakaalustamiseks on vajadus suurema kvaliteedikontrolli ja koostöö järele haridusekspertidega.

Erialase ettevalmistusega õpetaja - „digitark arengusuunaja“ - tegutseb tehnoloogilise arengu ja surve tingimustes ratsionaalselt, eetiliselt ja perspektiivitundega. Niisugune suundumus kujutab pööret õppimises ja hariduses tervikuna. Kooli roll ja eesmärgid muutuvad senisest ambitsioonikamateks. Tähelepanu koondub üldpädevuste ja inimese kui terviku arengule. See eeldab mõtteviisi muutust ühiskonnas ja hariduspoliitikas, interdistsiplinaarset koostööd tehnoloogiliste vahendite arendamisel, aga ka kriitilist hoiakut lihtsakoeliste digitehnoloogiliste vahendite suhtes. Tehnoloogia pakkumise paljusus nõuab õpetajalt nutikust, aga ka autonoomiat sobivaimate vahendite valimisel.

Ollakse üksmeelel, et õpetajatöö laiemad funktsioonid ja rollid nõuavad süvatasandi teadmisi pedagoogikast, psühholoogiast, haridusfilosoofiast ja -sotsioloogiast. Kuna õpetajate järelkasv sünnib akadeemilise tasemehariduse baasil, paneb haridustehnoloogia pealetung õpetajakoolituse proovile. Positiivse stsenaariumi puhul kasvab võimaluste paljususes õpetaja autonoomia oma õppe sisu ja vormi kujundamisel. Haridustöötajate, sealhulgas kooli ja ülikooli koostöö soodustab õpetajate professionaalset arengut, väärtuspõhimõtete jagamist.

Ranged sisenemistingimused võivad tekitada ajutisi tagasilööke, ent kokkuvõttes tõstavad need õpetajate staatust, hariduse kvaliteeti ning soodustavad tehnoloogia tõhusat rakendamist. „Digitark arengusuunaja“ on oma pädevuse ja praktikate poolest kooskõlas töömaailma vajadustega, ent kutse-eetikast lähtudes toetab õppija isiksuslikku arengut. Teisalt kasvavad ka tehnoloogia varjuküljed: õpetajate küberkiusamine, piiride ähmastumine töö ja eraelu vahel. Kuna suur osa õppimisest ja õpetamisest leiab aset veebikeskkonnas, on kolleegidest füüsilisse isolatsiooni jäämise oht.

\section{II „Tehnoloogiakaubamaja instruktor“}

Konservatiivsemate poliitikate tulemusena kasvab riigi roll hariduse korraldamisel (Jakobson et al., 2011, 137). Riik soovib rangemalt reguleerida õpetajaametisse sisenemist ning välistada era- ja kolmandast sektorist lähtuvad sisenemisteed. Õpetajatest kujunevad lojaalsed riigiametnikud, kellel ei saa olla väga suurt autonoomiat, kuid võib olla suhteliselt kõrge staatus, kuna riik delegeerib neile võimu. Selle stsenaariumiga haakuvad ka instrumentaalsemad eesmärgid hariduses (nt ettevalmistus riigile vajalikeks ametiteks) ja ka 
haridustehnoloogia arengus. Õpetajate ettevalmistus jääb akadeemiliseks ja on ülikoolide halduses. Koolivälise keskkonna muutumine üha tehnoloogiarikkamaks, tehnoloogiatööstuse surve, õpikeskkondade avardumine, nõudlus individualiseerituma hariduse järele jms sunnivad õpetajate ettevalmistust ja täienduskoolitust kriitiliselt ümber hindama. Suure tähelepanu all on õpetajate tehnoloogiliste pädevuste kujundamine.

Haridustehnoloogiate arendamine lähtub peamiselt turunõudlusest, olles piiratud üksikute õpetajatöö aspektide või tegevuste automatiseerimisega (Tuomi, 2018). Tehnoloogia võimaldab õppijat, sealhulgas erivajadustega õppijat, toetada ning õppimist mitmekesistada. Toetudes seejuures peamiselt traditsioonilistele õpikäsitlustele, kinnistab tehnoloogia olemasolevaid ainekeskseid õpetamispraktikaid ja õpetaja traditsioonilist rolli. Kuna haridustehnoloogiliste vahendite hankimise ja kasutamise võimalused sõltuvad kooli ressurssidest, võivad digilõhed koolide vahel kasvada (OECD, 2019b). Tehnoloogiliste võimaluste ebaühtlust ja õpetajate puudust üritatakse leevendada suurte õppekeskuste ja hiigelklasside loomisega, mida õpetaja instruktorina haldab.

Kuna õpetajal on olemas piisavad pedagoogilised ja tehnoloogilised pädevused, on tehnoloogia valik peamiselt õpetaja professionaalse otsustamise küsimus. Tehnoloogiarohke, kuid kitsalt töömaailmale ja hetkevajadustele orienteeritud kool ei suuda pakkuda kõigile õpetajatele sobivat rakendust. Hea ettevalmistusega õpetaja soovib enamat kui valida riiklikult heakskiidetud materjale, analüüsida testitulemusi ja instrueerida õpilasi õppekeskkondade küsimustes. Seetõttu võivad rohkem õppija arengule keskenduvad õpetajad kaotada motivatsiooni ning pettuda.

\section{III „Biheivioristlik tööampsutaja“}

Hariduskulude kokkuhoid, õpetajate ja haridusteadlaste seisukohtadest eraldi kulgev hariduspoliitika ning turumehhanismid süvendavad õpetajate kriisi. Sellele otsitakse leevendust paindlikumatest sisenemisteedest õpetajaametisse (OECD, 2005), mis tähendab ka erialase ettevalmistuseta õpetajate ja ajutise tööjõu ehk nn tööampsutajate kasvu (Berg et al., 2018). Tehnoloogia haridusse integreerimist põhjendatakse kitsalt tuleviku töömaailma vajadustega, ent hinnatakse ka tehisintellekti potentsiaali ópetajate asendusvajaduse leevendamisel ja kvalifikatsioonita õpetajate töö lihtsustamisel.

Tehnoloogia rakendamisel lähtutakse pigem võistluslikkusest ja ajaga kaasas käimise printsiipidest. Õppekavasid järgivad haridustehnoloogilised lahendused automatiseerivad osa õpetajatööga seotud ülesandeist ja õpetajast saab õpikeskkondade haldaja. Suureneb e-õppepäevade osakaal. 
Õpilased varustatakse spetsiaalsete programmide või virtuaalsete juhendajatega (Johnson, \& Lester, 2016), mis toetavad konkreetsete teadmiste õppimist. Klassikursused asenduvad nõrgalt seotud rühmadega, mis on koondunud ulatuslikeks õpivõrgustikeks. Ähmastuvad piirid õppimise ja vaba aja vahel, sest igasugune infovahetus või interaktiivne mäng võib olla osa õppimisest (OECD, 2019b).

Tehnoloogiaga kaasnevate väljakutsetega toimetulek eeldab tuge õppijale, mida pedagoogilise ettevalmistuseta õpetajad tõenäoliselt pakkuda ei suuda. On oht, et tehnoloogiat rakendatakse tasakaalustamatult ja pigem biheivioristlikule lähenemisele vastavalt, mis tähendab soovitud käitumiste ja teadmiste kujundamist teatud stiimulite (premeerimise ja karistuse) kaudu. Virtuaal- ja liitreaalsust rakendatakse õppijate motivatsiooni tõstmise eesmärgil preemiana tulemusliku soorituse eest. Tähelepanuta jäävad õpitu mõtestamine, analüüs, enesetunnetus. Teadmiste puudumise ja õpilase-õpetaja kontaktide vähenemise tõttu ei suuda õpetajad õpilaste arengut toetada. Suureneb noorte ebakindlus ja riskirühma laste väljalangemus. Tuleviku määramatustega toimetulekuks ei piisa tehnoloogilistest oskustest ja fragmenteeritud teadmistest. Vaja on mõista tervikut, inimliku olemuse sisu, arengu ja eneseteostuse olulisust - seega oskusi ja väärtusi, mis kitsalt instrumentaalse suundumuse korral tähelepanuta jäävad ja mida erialase ettevalmistuseta õpetaja piisavalt ei toeta.

Õpetajatöö automatiseerimine ja erialase ettevalmistuseta õpetajate arvukus kahandavad õpetajate autoriteeti. Kuna avatud sisenemine ei toeta õpetajate identiteedi ja kuuluvustunde kujunemist, on oht, et õpetajate kutseühendused ja koostöövõrgustikud hääbuvad, kaob ametirühmasisene kvaliteeti tagav kontroll ja arusaam õpetajaametist. Ametialase ettevalmistuseta õpetajaid riivavad autonoomia puudumine või madal staatus vähem. Suureneb õpetajaskonna voolavus ja haridusinstitutsioon nõrgeneb.

\section{IV „Arenguline paradoks“}

Tehnoloogia arenguline suundumus võib hakata õpetajate professionalismi mõjutama siis, kui tehnoloogia loojad asuvad koostööle haridusekspertidega, kes rõhutavad üldpädevuste ja väärtuspõhise hariduse olulisust. Tehisintellekti kasutamisega seotud optimistliku hoiaku tõttu omistatakse tehnoloogiale võimet osaliselt kompenseerida õpetajate piiratud võimeid, näiteks anda õppijatele kiiremini tagasisidet (Holmes, Bialik, \& Fadel, 2019, 24).

Tehisintellekt võimaldab õpianalüütikat kasutades disainida õpilaste tasemele vastavaid veebipõhiseid õppeprogramme ning korraldada õpetajast järjekindlamalt individualiseeritud ja motiveerivat tagasisidestamist. Samas valitseb oht, et tehisintellekti potentsiaali hinnatakse üle. Tehnoloogia võimaluste 
avardudes vajatakse õpetajaid, kes hindaks tehnoloogia positiivseid ja negatiivseid külgi kriitiliselt ning võimaldaks õppijatele inimlikku kontakti ja emotsionaalset tuge. Siiski pole välistatud, et osa üldpädevusi, nagu refleksioonioskust, võib tulevikus arendada ka tehnoloogia toel.

Võib arvata, et avatud sisenemisel õpetajaametisse on õpetajate pedagoogiline ettevalmistus sellisteks ülesanneteks ebapiisav. Lühiajalistel tööampsutajatest õpetajatel ei kujune välja jagatud kutseidentiteeti ning kannatab pühendumus tööle ja lojaalsus kooli ja õpilaste suhtes. Õpetamisest saab teenus, mida on võimalik tellida platvormipõhiselt (Berg et al., 2018). Õpilase ja õpetaja personaalsed sidemed ei kujune välja, mistõttu on see katastroofistsenaarium eelkõige noorematele õpilastele.

Tehnoloogiat võidakse kasutada ka õpetaja töö hindamiseks. Kuna õpetajad tunnetavad seda autonoomiat piirava kontrollina, väheneb nende julgus individuaalseid lahendusi katsetada. Tehisintellekti areng, õpetaja vähene autonoomia ja avatud sisenemine toovad kaasa ópetajakutse staatuse languse. Eeldatavasti leidub õpetajate hulgas missioonitundega entusiaste, kes pööravad tähelepanu kasvatusküsimustele ning arengule. Nendest kujunevad õppijatele tugiisikud, kellele võib lootma jääda.

Avatud sisenemine õpetajakutsesse leevendab õpetajate puudust vaid ajutiselt. Inimese üldist arengut toetava tehnoloogia poole püüdlemine on vastuolus madalate pädevusnõuetega, mis iseloomustab avatud sisenemist õpetajaametisse. On poliitilise valiku küsimus, kas tahetakse ajutiselt leevendada õpetajate põuda mittekvalifitseeritud õpetajatega, kes on võimelised instrumentaalselt tehnoloogiat rakendama, või panustame hea erialase ja pedagoogilise ettevalmistusega õpetajatesse, kes suudavad tehnoloogia abil toetada õppijate üldist arengut.

\section{Diskussioon}

Erinevate tegurite seast on valitud õpetaja tuleviku töökeskkonda kujundavate võtmeteguritena haridustehnoloogia suundumused ja sisenemisteed õpetajaametisse. Nende alusel on kirjanduse analüüsile toetudes visandatud neli võimalikku õpetaja professionalismi stsenaariumi: „digitark arengusuunaja“, „tehnoloogiakaubamaja instruktor“, „biheivioristlik tööampsutaja“ ja „arenguline paradoks“.

Stsenaariumimeetod, mille abil püütakse vaadata tulevikku, toetudes praegusele teadmisele ja visioneerides, kuidas võtmetegurid tuleviku óppimise ja õpetaja töökeskkonda mõjutavad, ei pretendeeri stsenaariumide suurema või väiksema tõenäosusega realiseeerumise selgitamisele. Pigem on see katse 
õppida võimalikest tulevikuteedest ja ärgitada edasisi strateegilisi arutelusid õpetaja töö ja ameti tuleviku teemal.

Võimalikud stsenaariumid ei too kaasa ühemõtteliselt head ega halba - igaühes on midagi, mis pakub probleemidele lahendusi ja tekitab või süvendab probleeme. Näiteks esimesed kaks stsenaariumi, mis põhinevad õpetajate akadeemilisel ettevalmistusel ülikoolides, annavad õpetajatele tõenäoliselt parema pedagoogilise, tehnoloogilise ja ainealase ettevalmistuse kui viimased kaks, avatud sisenemisteedest lähtuvat stsenaariumit, tõstes seega ka nende staatust.

Õpetajate professionaalsuse avaldumine sõltub muu hulgas nii kogu haridusvaldkonna kui ka konkreetse haridusasutuse tehnoloogilisest orientatsioonist. Kuna koolid võivad olla üsna erineva koolikultuuriga, võib selles kontekstis rääkida ka organisatsioonilisest või hübriidprofessionalismist, mis kujuneb välja õpetajate enda ametirühma ning organisatsioonist johtuvate väärtuste ja nõudmiste põimudes (Evetts, 2013; Noordegraaf, 2007). Instrumentaalse suundumuse puhul tehnoloogias (stsenaariumid II ja III) kujuneb õpetajatel tõenäolisemalt välja nn kitsas professionaalsus ja arengulise vaate puhul (stsenaariumid I ja IV) pigem avar professionaalsus. „Digitark arengusuunaja“ vastab Hoyle'i avara professionaali mudelile (1975), kes otsib pidevalt enesearengu võimalusi, teeb koostööd kolleegidega, osaleb tehnoloogiarikastes õpetajate professionaalsetes võrgustikes ning kasutab ja arendab tehnoloogiat mõtestatult, õppija arengut toetavalt.

Teise stsenaariumi õpetaja, „tehnoloogiakaubamaja instruktor“ haakub Hoyle’i kitsa professionaali käsitlusega (1975). Õpetaja valib tehnoloogilisi valmislahendusi instrumentaalsetel eesmärkidel, konkreetsete oskuste või aineteadmiste õpetamiseks, mis aitaksid tõsta õppijate punktiskoore eksamitel. Avaramad pedagoogilised eesmärgid, näiteks kooliarendus ja koostöö teiste õpetajatega õppija arengu toetamiseks, ei sobi kokku instrumentaalsusega. „Digitarga arengusuunaja“ stsenaarium tundub esmapilgul eelistatavaim, sest lähtub õppija holistlikust arengust. Samas võib see kaasa tuua õpetajate ülekoormuse suurenemise, sest eeldab pidevat valmisolekut veebis uusi materjale luua ja õpilasi tagasisidestada, kusjuures kaovad piirid töö ja eraelu vahel (OECD, 2019b, tabel 1.1).

Teised kaks stsenaariumi, „biheivioristlik tööampsutaja“ ja „arenguline paradoks", lähtuvad avatud sisenemisest õpetajakutsesse, mille puhul on trend üldiselt lühemaajalise ja praktilisema ettevalmistuse poole, kus võib vajaka jääda õpetajaametiks vajaliku interdistsiplinaarse teadmise ja nn suure pildi hoomamisest hariduses. Selles võtmes käsitleme õpetajat pigem kui tehnoloogi, kelle autonoomia on piiratud ja staatus pole seetõttu kuigi kõrge. Samas ei pruugi piiratud autonoomia kitsa professonaalsusega õpetajat tehnoloogia 
instrumentalistliku ja biheivioristliku suunitluse puhul eriti häirida, kuna tööülesanded on konkreetsemalt piiritletud ja defineeritud ning seetõttu kergemini teostatavad. Viimase stsenaariumi puhul tekib tunnetuslik ebakõla või arenguline paradoks, kus õpetaja pinnapealne ettevalmistus ning tehnoloogia arenguline suundumus on omavahel vastuolus. See ei luba õpetajatel saavutada tehnoloogia arengulisi eesmärke või vähemalt ei suuda nad tehnoloogiakasutust piisavalt mõtestada.

Küsitav on ka, milline stsenaarium oleks õpetajate praeguse põua leevendamiseks parim. Kuigi hea akadeemilise ettevalmistusega õpetajad kipuvad olema kutsekindlamad kui avatud sisenemisteede kaudu leitud õpetajad (OECD, 2005), ähvardab neid eriti tehnoloogia arengulise suundumuse puhul pidevast uute tehnoloogiate õppimisvajadusest tulenev ülekoormus ja läbipõlemine (Harris, Mishra, \& Koehler, 2009), kuna ootused nende pädevustele on ülikõrged ning tööks vajalik ajaressurss ning töötasu ilmselt ikkagi ebapiisavad (Bataineh \& Alsagheer, 2012 6; Scott, 2019, 3). Kõrgete ootuste täitmist takistab praegu ka fakt, et $24 \%$ Eesti õpetajatest (võrreldes $20 \%$ OECD riikides keskmiselt) peab enda digioskusi ebapiisavateks (OECD, 2019c). Seetõttu võib õpetajatööle jäävaid õpetajaid küll saata kangelase oreool, kuid pikemas perspektiivis ei lahenda see õpetajate kriisi.

Tehnoloogia instrumentalistlik suunitlus esitab õpetajatele tagasihoidlikumad nõuded ja võib ehk õpetaja tööaega kokku hoida, mistõttu väheneb nii avatud kui ka suletud sisenemistee puhul õpetajate ülekoormus. See võib eriti õpetaja kutseidentiteeti tugevdava akadeemilise ettevalmistuse puhul mõjuda uute õpetajate leidmisele ja kogenud õpetajate kutsekindlusele pigem hästi. Samas on 21. sajandil õpetajatööle esitatud kõrgendatud nõudmised kooskõlas hea akadeemilise ja praktilise õpetajaharidusega ning tehnoloogia arengulise suundumusega.

Tundub, et õpetajatöö ideaali ja reaalsuse vahel laiutab sügavik: mida idealistlikumad on ootused õpetajatööle, seda enam tajutakse ebakõla reaalsete ressursside ja oskustega. Tulemuseks on kas ideaalidest kaugenemine või läbipõlemine. Kitsamalt ja seega realistlikumalt defineeritud eesmärkide puhul võib aga esialgne rahulolu saavutustega asenduda peagi igatsusega suuremate väljakutsete ja suurema autonoomia järele. Ükskõik, millise stsenaariumi poole õpetaja professionalism tulevikus võib kalduda, tuleks läbi mõelda, kuidas meelitada õpetajatööle võimekaid inimesi ja mõista, mis neid motiveerib: kas suured ja üllad eesmärgid või kitsalt piiritletud ülesanded. Tuleks analüüsida, kuidas neid selleks ette valmistada ja kogu karjääri vältel toetada. 


\section{Tänusõnad}

Artikkel on valminud IUT18-2 teadusteema „Õpetajate professionaalsuse ja professionalismi muutuv kontekst (01.01.2014-31.12.2019)“ toel, mida rahastab sihtasutus Eesti Teadusagentuur.

\section{Kasutatud kirjandus}

Arenguseire Keskus (2018). Tööturg 2035. Tööturu tulevikusuunad ja-stsenaariumid. Tallinn: Arenguseire Keskus. Külastatud aadressil https://www.riigikogu.ee/ wpcms/wp-content/uploads/2018/08/tooturg_2035_tooturu_tulevikusuunad_ja_ stsenaariumid_A4_veeb.pdf

Ball, S. (1994). Education reform: A critical and post-structural approach. Buckingham: Open University Press.

Ball, S. (2006). Good school/ bad school. Paradox and fabrication. In Education Policy and Social Class. The selected works of Stephen J. Ball (pp. 96-114). London and New York: Routledge.

Bataineh, O., \& Alsagheer, A. (2012). An investigation of social support and burnout among special education teachers in the United Arab Emirates. International Journal of Special Education, 27(2), 5-13.

Berg, J, Furrer, M., Harmon, E., Rani, U, \& Silberman, M. S. (2018). Digital labour platforms and the future of work: Towards decent work in the online world. International Labour Organization. Geneva. Külastatud aadressil https://www.ilo.org/ wcmsp5/groups/public/---dgreports/---dcomm/---publ/documents/publication/ wcms_645337.pdf

Bjekic, D., Obradovic, S., Vučetic, M., \& Bojovic, M. (2013). E-teacher in inclusive e-education for students with specific learning disabilities. Procedia-Social and Behavioral Sciences, 128, 128-133. https://doi.org/10.1016/j.sbspro.2014.03.131

Doll, W. E. (1993). A Post-Modern Perspective on Curriculum. New York: Teachers College Press.

Edwards, B. I., \& Cheok, A. D. (2018). Why Not Robot Teachers: Artificial Intelligence for Addressing Teacher. Applied Artificial Intelligence, 32(4), 345-360. https://doi.org/10.1080/08839514.2018.1464286

Eesti Õpetajate Liit (2005). Eesti õpetajaeetika koodeks. http://www.opetajateliit.ee/?page_id=287

EHIS - Eesti Hariduse Infosüsteem.

Erss, M. (2015). The politics of teacher autonomy in Estonia, Germany, and Finland. Sotsiaalteaduste dissertatsioonid. Tallinna Ülikool.

Erss, M., Kalmus, V., Autio, T. (2016). 'Walking a Fine Line': Teachers' Perception of Curricular Autonomy in Estonia, Finland and Germany. Journal of Curriculum Studies, 48(5), 589-609. https://doi.org/10.1080/00220272.2016.1167960

Evetts, J. (2013). Professionalism: Value and ideology. Current Sociology Review, 61(5-6), 778-796. https://doi.org/10.1177/0011392113479316 
Evetts, J. (2014). The Concept of Professionalism: Professional Work, Professional Practice and Learning. In: Billett S., Harteis C., Gruber H. (eds) International Handbook of Research in Professional and Practice-based Learning (pp. 29-56). Springer International Handbooks of Education. Springer, Dordrecht.

Freidson, E. (2001). Professionalism: The third logic. Cambridge: Polity Press.

Fullan, M. (2013). Stratosphere: Integrating technology, pedagogy, and change knowledge. Pearson Canada Inc.

Fuller, T, Loogma, K. (2009). Constructing futures; a social constructionist perspective on foresight methodology. Futures, 41(2), 71-79. https://doi.org/10.1016/j.futures.2008.07.039

Goodson, I. (2003). Professional knowledge, professional lives: Studies in education and change. Maidenhead, Philadelphia: Open University Press.

Greenfield, P. M. (2009). Technology and informal education: What is taught, what is learned. Science, 323, 69-71. https://doi.org/10.1126/science.1167190

Hargreaves, A. (2006). Four ages of professionalism and professional learning. In H. Lauder, P. Brown, J.-A. Dillabough, \& A. H. Halsey (Eds.), Education, globalization, and social change (pp. 672-691). Oxford: Oxford University Press.

Hargreaves, A., \& Shirley, D. (2009). The fourth way: The inspiring future for educational change. Corwin Press. https://doi.org/10.4135/9781452219523

Harris, J.; Mishra, P.; Koehler, M. (2009). Teachers' technological pedagogical integration reframed. Journal of Research on Technology in Education, 41(4), 393-416. https://doi.org/10.1080/15391523.2009.10782536

Henriksen, D., Mishra, P., \& Fisser, P. (2016). Infusing creativity and technology in 21st century education: A systemic view for change. Educational Technology \& Society, 19(3), 27-37.

Hoyle, E. (1975). Professionality, professionalism and control in teaching. In V. Houghton, R. McHugh, \& C. Morgan (Eds.), Management in education: The management of organisations and individuals (pp. 314-320). London: Ward Lock Educational in association with Open University Press.

Hoyle, E. (2001). Teaching as a profession. International Encyclopedia of the Social and Behavioural Sciences, 15472-15475. https://doi.org/10.1016/B0-08-043076-7/02450-5

Holmes, W., Bialik, M., \& Fadel, C. (2019). Artificial intelligence in education: Promises and implications for teaching and learning. Boston: Center for Curriculum Redesign. Külastatud aadressil https://curriculumredesign.org/wp-content/ uploads/AIED-Book-Excerpt-CCR.pdf

Hrastinski, S., Olofsson, A. D., Arkenback, C., Ekström, S., Ericsson, E., Fransson, G., Jaldemark, J., Ryberg, T., Öberg, L.-M., Fuentes, A., Gustafsson, U., Humble, N., Mozelius, P., Sundgren, M., \& Utterberg, M. (2019). Critical imaginaries and reflections on artificial intelligence and robots in postdigital K-12 education. Postdigital Science and Education, 1, 427-445. https://doi.org/10.1007/s42438-019-00046-x

HTM (2019a). Strateegiline planeerimine aastateks 2021-2035. Haridus- ja Teadusministeerium. Külastatud aadressil https://www.hm.ee/et/kaasamine-osalemine/ haridus-ja-teadusstrateegia-aastateks-2021-2035 
HTM (2019b). Ülevaade haridussüsteemi välishindamisest 2018/2019. õppeaastal. Tartu: Haridus- ja Teadusministeerium. Külastatud aadressil https://docplayer. ee/168515306-\%C3\%BClevaade-hariduss\%C3\%BCsteemi-v\%C3\%A4lishindamisest-2018-2019-\%C3\%B5ppeaastal.html

Jakobson, M.-L., Kalev, L., Lumi, O., Ruutsoo, R., Saarts, T., Sootla, G., Toots, A., Vetik, R. (2011). Poliitilised ideoloogiad. L. Kalev ja A. Toots (Toim). Poliitika ja valitsemise alused. Kõrgkooliõpik. Tallinn: Tallinna Ülikool.

Johnson, W. L., \& Lester, J. C. (2016). Face-to Face Interaction with Pedagogical Agents, Twenty Years Later. Int J Artif Intell Educ, 26, 25-36. https://doi.org/10.1007/s40593-015-0065-9

Kahn, H., \& Wiener, A. J. (1967). The year 2000: A framework for speculation on the next thirty three years. New York: Hudson Institute.

Kalyuga, S., \& Liu, T.-C. (2015). Guest editorial: Managing cognitive load in technology-based learning environments. Educational Technology \& Society, 18(4), 1-8.

Kirkpatrick, I., \& Noordegraaf, M. (2015). Organizations and occupations: Towards hybrid professionalism in professional service firms? In L. Empson, D. Muzio, J. Broschak, and B. Hinings (Eds.), The Oxford Handbook of Professional Service Firms. Oxford University Press.

Kolnes, M., \& Konstabel, K. (2018). Tugispetsialistide arvu ja vajaduse hindamine. Tartu: Innove.

Kõiv, K. (2015). Changes over a ten-year interval in the prevalence of teacher targeted bullying. Procedia - Social and Behavioral Sciences, 171, 126-133. https://doi.org/10.1016/j.sbspro.2015.01.098

Lauristin, M., Loogma, K., Ene-Mall Vernik-Tuubel, E-M., Kutsar, D., Erss, M., Kallas, K., Sildnik, A., Käosaar, I (2019). Heaolu ja sidususe visioon. Eesti haridusja teadusstrateegia 2021-2035. Tartu: Haridus- ja Teadusministeerium. Külastatud aadressil_https://www.hm.ee/sites/default/files/haridus-_ja_teadusstrat_2035_ heaolu_ja_sidususe_visioon.pdf

Lave, J., \& Wenger, E. (1991) Situated learning: Legitimate peripheral participation. Cambridge: Cambridge University Press. https://doi.org/10.1017/CBO9780511815355

Luik, P (2013). Haridustehnoloogia. R. Mikser (toim), Haridusleksikon. Tallinn: Eesti Keele Sihtasutus.

Loogma, K (2014). Conceptualizing Teachers' Professionalism: the Case of Estonian Lower Secondary Teachers. In: Airi Liimets, Marika Veisson (Eds.), Teachers and Youth in in Educational Reality (11-22). Frankfurt am Main: P. Lang. (Baltische Studien zur Socialwissenschaften; 27).

Mac Iver, M. A., \& Mac Iver, J. D. (2015). STEMming the swell of absenteeism in urban middle grade schools: Impacts of a summer robotics program. Urban Education, 54(1). https://doi.org/10.1177/0042085915618712

Mets, U., \& Viia, A. (2018). Tulevikuvaade töojõu- ja oskuste vajadusele: haridus ja teadus. Uuringu lühiaruanne. Tallinn: SA Kutsekoda / OSKA.

Noordegraaf, M. (2007). From „pure“ to „hybrid“ professionalism. Present-day professionalism in ambiguous public domains. Administration \& Society, 39(6), 761781. https://doi.org/10.1177/0095399707304434 
O’Donnell, A. (2015). Contemporary pedagogy and mindfulness: Developing creative attention in an age of distraction. Journal of Philosophy of Education, 49(2), 187-202. https://doi.org/10.1111/1467-9752

OAJ (Opetusalan Ammattijärjestö) (2020). Jäsennyys ja jäsenedut. Opetusalan Ammattijärjestö. Külastatud aadressil https://www.oaj.fi/

OECD (2001). Scenarios for the future of schooling. Külastatud aadressil https://www.oecd.org/site/schoolingfortomorrowknowledgebase/futuresthinking/scenarios/scenariosforthefutureofschooling.htm

OECD (2005). Teachers matter. Attracting, developing and retaining effective teachers. Overview. OECD Publishing. Külastatud aadressil https://www.oecd.org/education/school/34990905.pdf

OECD (2016a). Innovating education and educating for innovation: The power of digital technologies and skills. Paris: OECD Publishing. https://doi.org/10.1787/9789264265097-en

OECD (2016b). PISA 2015 results. Volume I. Excellence and equity in education. OECD Publishings. https://doi.org/10.1787/9789264266490-en

OECD (2018). The future of education and skills 2030. Learning framework 2030. OECD. Külastatud aadressil http://www.oecd.org/education/2030/E2030\%20Position\%20Paper\%20(05.04.2018).pdf

OECD (2019a). TALIS 2018 Results (Volume I): Teachers and school leaders as lifelong learners. Paris: OECD Publishing. Külastatud aadressil https://doi.org/10.1787/1d0bc92a-en

OECD (2019b). How's life in the digital age? Opportunities and risks of the digital transformation for people's well-being. OECD. Külastatud aadressil https://www.oecd-ilibrary.org/science-and-technology/how-s-life-in-the-digitalage_9789264311800-en

OECD (2019c). How's life in the digital age in Estonia? In How's life in the digital age? Opportunities and risks of the digital transformation for people's well-being. OECD. Külastatud aadressil https://www.oecd-ilibrary.org/sites/9789264311800-13-en/ index.html?itemId=/content/component/9789264311800-13-en

Olssen, M., Codd, J., \& O’Neill, A.-M. (2004). Education policy: Globalization, citizenship, and democracy. London: Sage Publications.

Pedaste, M., Leijen, Ä., Poom-Valickis, K., \& Eisenschmidt, E. (2019). Teacher professional standards to support teacher quality and learning in Estonia. European Journal of Education, 54(3), 389-399. https://doi.org/10.1111/ejed.12346

Pinar, W. F. (2004). What is curriculum theory? Mahwah, New Jersey, London: Lawrence Erlbaum Associates, Inc.

Pötzsch, H. (2019). Critical Digital Literacy: Technology in Education Beyond Issues of User Competence and Labour-Market Qualifications. tripleC, 17(2), 221-240. https://doi.org/10.31269/triplec.v17i2.1093

Raidt, T. (2009). Bildungsreformen nach PISA. Paradigmenwechsel und Wertewandel. Inauguraldissertation im Fach Soziologie/Bildungssoziologie zur Erlangung des Doktorgrades der Philosophischen Fakultät der Heinrich-Heine-Universität Düsseldorf. Stuttgart.

Ramirez, R., \& Wilkinson. A. (2014). Rethinking the $2 \times 2$ scenario method: Grid or frames? Technological Forecasting \& Social Change 86, 254-264.

https://doi.org/10.1016/j.techfore.2013.10.020 
Regan, P. M. \& Khwaja, E. T. (2019). Mapping the political economy of education technology: A networks perspective. Policy Futures in Education, 17(8), 10001023. https://doi.org/10.1177/1478210318819495

Rosenfeld, K. N. (2015). Digital Online Culture, Identity, and Schooling in the TwentyFirst Century. Palgrave Macmillan.

RT (Riigi Teataja) (2013). Direktori, õppealajuhataja, õpetajate ja tugispetsialistide kvalifikatsiooninõuded. RT I, 30.08.2013, 5. riigiteataja.ee/akt/130082013005

Rumma, K. (Toim). (2017). Projekt „Õpikäsituse profiil“ uurimistulemuste raport. Tallinn: Haridus- ja Teadusministeerium, Tallinna Ülikool.

Ruus, V.-R. (2006). Õpetaja professionaalsuse ning õpetajahariduse kaasaegsed arengusuundumused. Tallinn: TLÜ Kirjastus.

Räis, M. L., \& Sõmer, M. (2016). Haridusliku erivajadusega õpilaste kaasav hariduskorralduse ja sellega seotud meetmete tõhusus. Temaatiline raport: kaasamise tähenduslikkus. Eesti rakendusuuringute keskus Centar. Külastatud aadressil https://centar.ee/uus/wp-content/uploads/2017/01/Teemaraport-Tahenduslikkusfinal.pdf

Schwartz, P. (1991). The art of the long view: Scenario planning - protecting your company against an uncertain world. Century Business.

Schwartz, P. (1997). The art of the long view: Planning for the future in an uncertain world. New York: John Wiley \& Sons.

Scott, S. B. (2019). Factors influencing teacher burnout and retention strategies. Williams Honors College, Honors Research Projects. 798. https://ideaexchange.uakron.edu/honors_research_projects/798

Scrimshaw, P. (2003). ICT in European schools: emerging issues from the ValNet project. The Curriculum Journal, 14(1), 85-104. https://doi.org/10.1080/0958517032000055992

Seddon, T. (2013). Making educational spaces through boundary work: territorialisation and „boundarying“. Globalisation, Societies and Education, 12(1), 10-31. https://doi.org/10.1080/14767724.2013.858396

Selliov, R. (2017). Osalus noorsootöös. Haridus- ja Teadusministeeriumi aasta-analüüs 2017. Eesti hariduse viis tugevust. Külastatud aadressil https://www.hm.ee/ sites/default/files/uuringud/eesti_noorte_osalemine_noorsootoos.pdf

Selliov, R., \& Vaher, K. (2018). Õpetajakoolituse lópetanud ja alustavad ópetajad EHISe andmetel. Tartu: Haridus- ja Teadusministeerium.

Selwyn, N. (2013). „Micro"Politics: Mapping the Origins of Schools Computing as a Field of Education Policy. History of Education, 42(5), 638-658. https://doi.org/10.1080/0046760X.2013.823628

Serholt, S., Barendregt, W., Vasalou, A., Alves-Oliveira, P., Jones, A., Petisca, S., \& Paiva, A. (2017). The case of classroom robots: teachers' deliberations on the ethical tensions. AI \& Society, 32(4), 613-631. https://doi.org/10.1007/s00146-016-0667-2

Spaniol, M., \& Rowland, N. (2018). Defining scenario. Futures Foresight Sci 2019; 1:e3. https://doi.org/10.1002/ffo2.3

Tark ja tegus Eesti 2035 (2019). Eesti haridus- ja teadusstrateegia 2021-2035. Tark ja tegus Eesti. Kolme ekspertrühma visioonidokumentide kokkuvõte. Haridus- ja Teadusministeerium. Külastatud aadressil https:/www.hm.ee/sites/default/files/ tark_ja_tegus_eesti2035_kokkuvottev_visioonidokument.pdf 
Tuomi, I. (2018). The impact of artificial intelligence on learning, teaching, and education. Policies for the future. M. Cabrera, R. Vuorikari \& Y. Punie (Eds.), Luxembourg: Publications Office of the European Union. DOI: 10.2760/12297

Tynjälä, P. (2008). Perspectives into learning at the workplace. Educational Research Review, 3(2008) 130-154. https://doi.org/10.1016/j.edurev.2007.12.001

Valk, A. (2016). Õpetajaameti atraktiivsus. Tartu: Haridus- ja Teadusministeerium.

Voltri, R. (2017). Eesti õpetajate esindamine. Oppetajate Leht, 10. nov. https://opleht.ee/2017/11/eesti-opetajate-esindamine/

Übius, Ü., Kall, K., Loogma, K. Ümarik, M. (2014). Rahvusvaheline vaade õpetamisele ja óppimisele. OECD Rahvusvahelise õpetamise ja õppimise uuringu TALIS 2013 tulemused. Tallinn: SA Innove. 


\title{
Possible future scenarios of teacher professionalism for 2035
}

\author{
Krista Loogma $^{a 1}$, Maria Erss $^{\mathrm{a}}$, Meril Ümarika, Maret Aasa ${ }^{\mathrm{a}}$ \\ ${ }^{a}$ School of Educational Sciences, Tallinn University
}

\begin{abstract}
Summary
Globally, the teaching profession has been subjected to a number of significant changes in the last few decades which have left teachers in a vulnerable position. Like in all democratic societies where multiple opinions can be expressed, there is no agreement in Estonian society regarding the questions: what is the function of education and who is a professional teacher? Instead, contradictory expectations of teachers are voiced from different stakeholders.

According to the vision document of the Estonian education strategy 2035, the most crucial problems in Estonia, regarding the future professionalism of teachers, are the low status of teachers along with the structural shortage of teachers, especially a lack of new teachers. The issues of teacher well-being, teacher burn-out, autonomy and agency are related to these problems. A teachers' ability to support the development of general and subject-matter competencies of students while helping them to reflect on their learning experiences from various contexts is gradually gaining importance (Lauristin et al. 2019).

The aim of this article is to envision how teacher professionalism and the teaching profession may change in Estonia by 2035 by analysing trends that shape it. First, the current situation of teachers in Estonia will be outlined, then key factors shaping the teaching profession will be identified and, finally, four alternative scenarios of possible development paths of teacher professionalism until 2035 will be envisioned.

Freidson defines professionalism as a set of institutional conditions which enable a profession to control their own work. These conditions are: 1) selfregulation which indicates the profession's control over their work tasks, division of work, working conditions and work results, 2) science-based academic education, 3) high status, privileges and influence in the society, 4) control over entrance requirements to the profession, 5) specific ideology and professional ethics (2001).
\end{abstract}

School of Educational Sciences, Tallinn University, Narva Road 25, Tallinn 10120 Estonia; loogma@tlu.ee 
Changing social contexts have brought about multiple concepts of professionalism. For example, Evetts (2013) distinguishes between institutional and organisational professionalism. Noordegraaf $(2007,2013)$ uses the term hybrid professionalism referring to the adoption of principles of both professional work and management. Hoyle (1975) distinguishes between professionalism and professionality. While interdependent, professionalism indicates the institutional dimension. Professionality can be understood as the unique approach that each teacher has to her/his work within the broader context of professional ideology. Depending on the work context, teacher education and experience, professionality can contain different pedagogical beliefs, procedures and methods which can imply narrow or extended professionality (Hoyle, 1975). According to Hoyle's theory, a narrow professional learns mainly from her/his own experience and is limited to the individual classroom activities while an extended professional also values theoretical knowledge, cooperation with colleagues and a wider organisational and societal mission of teachers.

This paper uses the scenario method which allows us to anticipate and construct future knowledge. Scenarios depend on different factors including unavoidable factors such as demographic processes and others which contain choices, for example political decisions (Schwartz, 1991). Based on the current situation, scenarios take account of external factors with the highest unpredictability which may shape the future conditions of a phenomenon or system (Spaniol \& Rowland, 2018, p. 9). Although scenarios are not absolutely proven statements or positions about the future, they may point at alternative choices on how to reach these future situations. Moreover, they can be seen as a starting point for a dialogue (OECD, 2001). The following steps were taken while applying the scenario method: first, the current situation of teacher professionalism was described on the basis of existing literature and data. Second, the driving forces that influence teacher professionalism in the external environment were analysed based on literature. These external forces included changes in technology, ideology, values and norms, as well as changes in future learning environments. Third, two key factors were extracted among the driving forces: technological developments in education along with entering the teaching profession. Fourth, the two key factors were paired as axes on a coordinate plane creating a $2 \times 2$ matrix, which forms the basis for four possible scenarios which are given in four quadrats. The horizontal axis depicts a continuum between openness and closeness in accessing the teaching profession while the vertical axis refers to choice between developmental and instrumental orientation of educational technology. Finally, scenario stories were composed. 
Developments in educational technology were chosen as one of the key factors because they will certainly influence the teaching and learning through changes in demand for life and job related skills. Educational technology will enable more personalised and flexible learning environments within learning networks as well as supporting students with special needs. However, it will directly affect the role of teachers, depending on the orientation of technology and the advancements of artificial intelligence. The instrumental orientation (OECD, 2016a) is triggered by economic calculations and teacher shortages where some of teachers' functions are replaced by technology. Furthermore, the development orientation emphasises maximising the human potential and general development of each student in the context of decreasing demand for specific skills in the labour market due to automation (Tuomi, 2018).

Another key factor that shapes teacher professionalism is access to the teaching profession which can be either closed or open. Differing paths to the teaching profession imply different types of teacher education. While closed access refers to traditional academic teacher education offered by universities with high demands on graduates regarding the subject-related and pedagogical competences, open access signifies alternative paths to teaching with usually lower competence expectations. Open access strategy is often used in the context of teacher shortage. The preferred way depends on political decisions and the education market.

We constructed the scenario framework as follows:

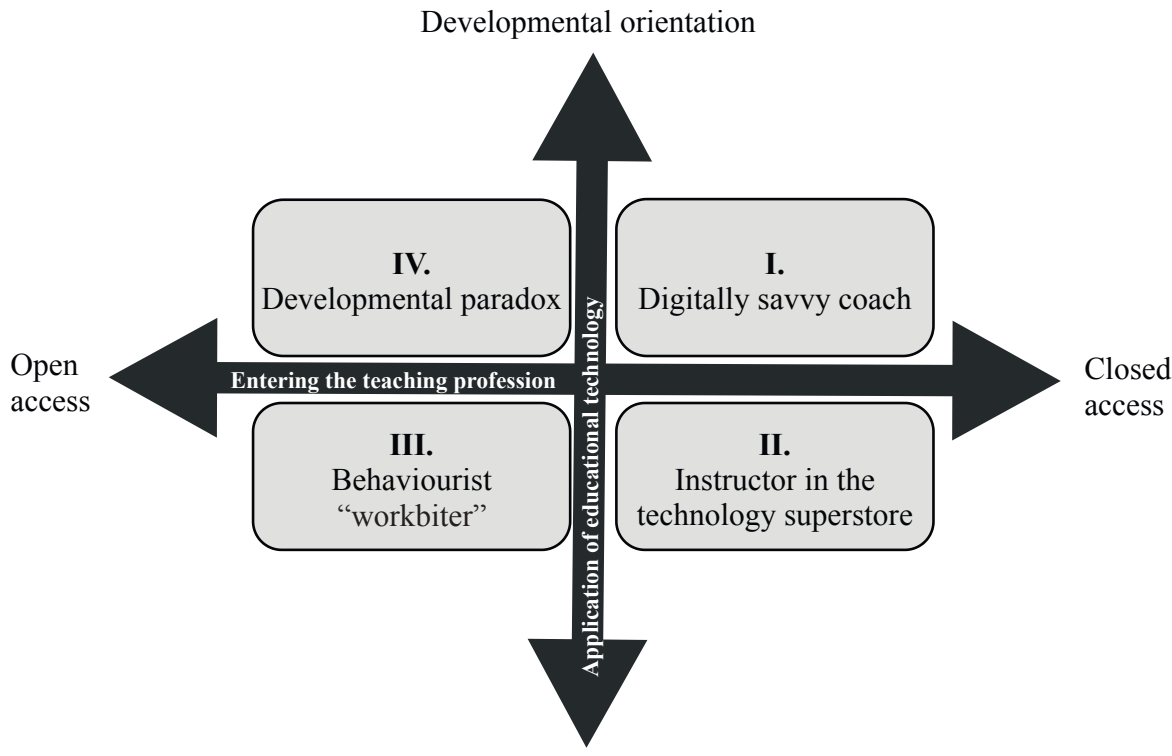

Instrumental orientation 
The scenarios cannot be interpreted as being simply good or bad. All of them contain something that may pose solutions to problems as well as create new or deepen existing problems. Scenarios I and II are likely to offer teachers a better subject-based and pedagogical training than scenarios III and IV, which may raise teachers' status. Since schools may exhibit different cultures and different technological orientations, we may as well speak of organisational or hybrid professionalism which is developed when the values and demands of teaching profession and educational organisations are symbiotically merged (Evetts, 2013, Noordegraaf, 2007).

Different technological orientations may trigger distinct forms of teacher professionality. The instrumental orientation will likely induce narrow professionality and the developmental orientation is more aligned with extended professionality as described by Hoyle (1974). Obviously, the "digitally savvy coach" with her/his readiness for self-development, cooperation and reflection is more capable of supporting the development of learners than the "instructor in the technology superstore" who focuses on using ready-made technological materials for achieving instrumental goals. Scenario I may therefore seem preferable to II. Yet, scenario I may lead to teacher burn-out from work overload along with fuzzy boundaries between work and free time in the online learning environments.

Scenarios III and IV assume that open access to teacher education may lead to teachers' lack of interdisciplinary knowledge and poor understanding of the "big picture" in education. Scenario IV poses a paradox where technology is developing faster and in a more progressive way than teacher education. Teachers' roles within these scenarios are more like technicians with behaviourist approach regarding teaching as a "workbite" which may lower their status and not be in line with the demands of the $21^{\text {st }}$ century expectations. On a brighter note, the more narrowly defined work tasks may be easier to accomplish. It seems the more idealistic the formal demands for teachers, the more the discrepancy between the real resources and skills. Yet, too narrowly defined tasks could lead to a yearning for more autonomy and challenge.

Which scenario is best to alleviate the structural lack of teachers in Estonia is debatable. The academic teacher education along with the developmental orientation of technology only contributes to teacher retention if the expectations are not set impossibly high to accomplish avoiding burn-out.

Keywords: professionalism, teachers, scenario method, key drives of future 